\title{
E-cadherin expression in plasmacytoid, signet ring cell and micropapillary variants of urothelial carcinoma: comparison with usual-type high-grade urothelial carcinoma
}

\author{
Matthew G Lim ${ }^{1}$, N Volkan Adsay ${ }^{1,2}$, David J Grignon ${ }^{3}$ and Adeboye O Osunkoya ${ }^{1,2,4}$ \\ ${ }^{1}$ Department of Pathology, Emory University School of Medicine, Atlanta, GA, USA; ${ }^{2}$ Emory Winship Cancer \\ Institute, Atlanta, GA, USA; ${ }^{3}$ Department of Pathology, Indiana University School of Medicine, Indianapolis, \\ IN, USA and ${ }^{4}$ Department of Urology, Emory University School of Medicine, Atlanta, GA, USA
}

Loss of E-cadherin expression has been linked to the invasive phenotypes of a variety of neoplasms, including lobular breast cancer. The expression of E-cadherin in variants of urothelial carcinoma relative to usual-type urothelial carcinoma, maximum depth of invasion and angiolymphatic invasion has not been well characterized. A total of eight cases of micropapillary urothelial carcinoma, four cases of plasmacytoid urothelial carcinoma, two cases of urothelial carcinoma with signet ring cell differentiation and two cases of urothelial carcinoma with mixed plasmacytoid and signet ring cell differentiation, all obtained from cystectomy/cystoprostatectomy cases, were identified. In all nine cases of usual-type invasive and noninvasive high-grade urothelial carcinoma were also included in the study. Immunohistochemical staining of E-cadherin was performed in all cases. Pathological parameters including depth of invasion and presence of angiolymphatic invasion were documented. Maximum depth of invasion: In micropapillary urothelial carcinoma, extravesical extension was seen in three of eight cases; muscularis propria invasion in four of eight cases; and lamina propria invasion in one of eight cases. In plasmacytoid urothelial carcinoma, extravesical extension was observed in two of four cases, and muscularis propria invasion and lamina propria invasion in one of four cases each. In urothelial carcinoma with signet ring cell differentiation, extravesical extension and muscularis propria invasion was seen in one of two cases each. In urothelial carcinoma with mixed plasmacytoid and signet ring cell differentiation, muscularis propria invasion and lamina propria invasion was observed in one of two cases each. In usual-type high-grade urothelial carcinoma, extravesical extension was seen in six of nine cases and noninvasive in three of nine cases. In angiolymphatic invasion, micropapillary urothelial carcinoma was observed in eight of eight cases; plasmacytoid urothelial carcinoma in two of four cases; urothelial carcinoma with signet ring cell differentiation in one of two cases; and urothelial carcinoma with mixed plasmacytoid and signet ring cell differentiation in one of two cases. Usual-type high-grade urothelial carcinoma was seen in six of nine cases. E-cadherin expression: All eight cases of micropapillary urothelial carcinoma were positive for E-cadherin in the micropapillary component and adjacent usual-type urothelial carcinoma. The four cases of plasmacytoid urothelial carcinoma, two cases of urothelial carcinoma with signet ring cell differentiation and two cases of urothelial carcinoma with mixed plasmacytoid and signet ring cell differentiation were all negative for E-cadherin. All nine additional cases of usual-type high-grade urothelial carcinoma were diffusely positive for E-cadherin. E-cadherin is diffusely positive in usual-type urothelial carcinoma and micropapillary urothelial carcinoma, irrespective of pathological stage and angiolymphatic invasion. Loss of E-cadherin expression may be a marker of plasmacytoid and signet ring cell differentiation in urothelial carcinoma.

Modern Pathology (2011) 24, 241-247; doi:10.1038/modpathol.2010.187; published online 3 September 2010

Keywords: E-cadherin; expression; urothelial carcinoma

Correspondence: Dr AO Osunkoya, MD, Department of Pathology, Emory University School of Medicine, Room H174, 1364 Clifton Road, NE, Atlanta, GA 30322, USA.

E-mail: adeboye.osunkoya@emory.edu

Received 4 June 2010; revised 22 July 2010; accepted 28 July 2010; published online 3 September 2010
The cadherins are a family of transmembrane glycoproteins that are involved in homotypic calcium-dependent intercellular adhesions and include N-, P- and E-cadherin. ${ }^{1}$ E-cadherin, the most extensively studied cadherin family member, is expressed in epithelial tissue and has an important 
role in establishment and maintenance of tissue architecture. ${ }^{2,3}$ Reduced expression or loss of E-cadherin has been reported in various human carcinomas. ${ }^{4-15}$ Aberrant expression of E-cadherin in human urothelial carcinoma is thought to correlate with lack of differentiation, muscle invasion and distant metastasis; however, this concept remains somewhat controversial. ${ }^{12,15-18}$

Greater than $90 \%$ of bladder carcinomas are usualtype urothelial carcinoma; however, a small subset of tumors are recognized as variants of urothelial carcinoma because of their distinctive histological appearance and/or poor prognosis. ${ }^{19,20}$ Two of these variant entities with poor prognosis are the plasmacytoid and micropapillary variants of urothelial carcinoma. The plasmacytoid variant is composed of discohesive oval-to-round cells with abundant eosinophilic cytoplasm and eccentrically located nuclei. Intracytoplasmic vacuoles may be present in these cells mimicking signet ring cells. This lesion may also be diffusely infiltrative or may be arranged in cords and in a single file pattern. ${ }^{21-23}$ The micropapillary variant may be comprised of two components, the superficial and invasive. The superficial component is comprised of slender filiform processes, often with a central fibrovascular core. The invasive component is comprised of small aggregates or nests of cells frequently seen in empty spaces 'retraction artifact' that mimic angiolymphatic invasion. Single tumor cells departing from the tight cell balls may be seen in the stroma. ${ }^{24,25}$

The expression of E-cadherin in variants of urothelial carcinoma relative to usual-type urothelial carcinoma, maximum depth of invasion and angiolymphatic invasion has not been well characterized. The goal of our study is compare E-cadherin expression in micropapillary, plasmacytoid and signet ring cell variants of urothelial carcinoma and usual-type urothelial carcinoma.

\section{Materials and methods}

We identified eight cases of micropapillary urothelial carcinoma, four cases of plasmacytoid urothelial carcinoma, two cases of urothelial carcinoma with signet ring cell urothelial carcinoma and two cases of urothelial carcinoma with mixed plasmacytoid and signet ring cell differentiation. A total of nine cases of usual-type invasive and noninvasive highgrade urothelial carcinoma were also included in the study. Immunohistochemical staining for E-cadherin (monoclonal antibody, clone: ECCD-2, 1:50, Zymed, South San Francisco, CA, USA) was performed in all cases. Immunohistochemical analysis was performed, after optimized epitope retrieval, with a polymer-based detection system. Sections were deparaffinized and rehydrated using deionized water. They were then heated in citrate buffer ( $\mathrm{pH}$ 6.0), using an electric pressure cooker for $3 \mathrm{~min}$ at $12-15$ p.s.i. (at $\sim 120^{\circ} \mathrm{C}$ ), and cooled for $10 \mathrm{~min}$ before staining. Fisher's exact test was performed to determine the statistical significance of E-cadherin expression in all cases. Each case was evaluated for depth of invasion and presence of angiolymphatic invasion. This study was completed following the guidelines of and with approval from the Emory University institutional review board.

\section{Results}

The immunohistochemical and pathological findings of eight cases of micropapillary urothelial carcinoma, four cases of plasmacytoid urothelial carcinoma, two cases of urothelial carcinoma with signet ring cell differentiation, two cases of urothelial carcinoma with mixed plasmacytoid and signet ring cell differentiation and nine cases of usual-type invasive and noninvasive high-grade urothelial carcinoma are listed in Table 1.

Immunohistochemical staining showed that all eight cases of micropapillary urothelial carcinoma were positive for E-cadherin in the micropapillary component and adjacent usual-type urothelial carcinoma (Figures 1a and b). The four cases of plasmacytoid urothelial carcinoma (Figures 2a and $b$ ), two cases with signet ring cell differentiation (Figures 3a and b) and two cases of urothelial

Table 1 Immunohistochemical and pathological findings in our cases of micropapillary urothelial carcinoma, signet ring cell urothelial carcinoma, plasmacytoid urothelial carcinoma, mixed plasmacytoid/signet ring cell urothelial carcinoma and nonvariant urothelial carcinoma

\begin{tabular}{|c|c|c|c|c|c|}
\hline & $\begin{array}{l}\text { Micropapillary } \\
\text { urothelial } \\
\text { carcinoma }\end{array}$ & $\begin{array}{l}\text { Plasmacytoid } \\
\text { urothelial } \\
\text { carcinoma }\end{array}$ & $\begin{array}{l}\text { Signet ring cell } \\
\text { urothelial } \\
\text { carcinoma }\end{array}$ & $\begin{array}{l}\text { Mixed plasmacytoid/ } \\
\text { signet ring cell } \\
\text { urothelial carcinoma }\end{array}$ & $\begin{array}{l}\text { Nonvariant } \\
\text { urothelial } \\
\text { carcinoma }\end{array}$ \\
\hline \multicolumn{6}{|l|}{ E-cadherin ${ }^{\mathrm{a}}$} \\
\hline Positive $^{\mathrm{a}}$ & $8 / 8$ & $0 / 4$ & $0 / 2$ & $0 / 2$ & $9 / 9$ \\
\hline Negative $^{a}$ & $0 / 8$ & $4 / 4$ & $2 / 2$ & $2 / 2$ & $0 / 9$ \\
\hline \multicolumn{6}{|l|}{ Pathological findings } \\
\hline Angiolymphatic invasion & $8 / 8$ & $2 / 4$ & $1 / 2$ & $1 / 2$ & $9 / 9$ \\
\hline Lamina propria invasion & $1 / 8$ & $1 / 4$ & $0 / 2$ & $1 / 2$ & $0 / 9$ \\
\hline Muscularis propria invasion & $4 / 8$ & $1 / 4$ & $1 / 2$ & $1 / 2$ & $3 / 9$ \\
\hline Extravesical extension & $3 / 8$ & $2 / 4$ & $1 / 2$ & $0 / 2$ & $6 / 9$ \\
\hline
\end{tabular}

${ }^{\mathrm{a}}$ Fisher's exact test: $P$-value $\leqslant 0.0001$. 

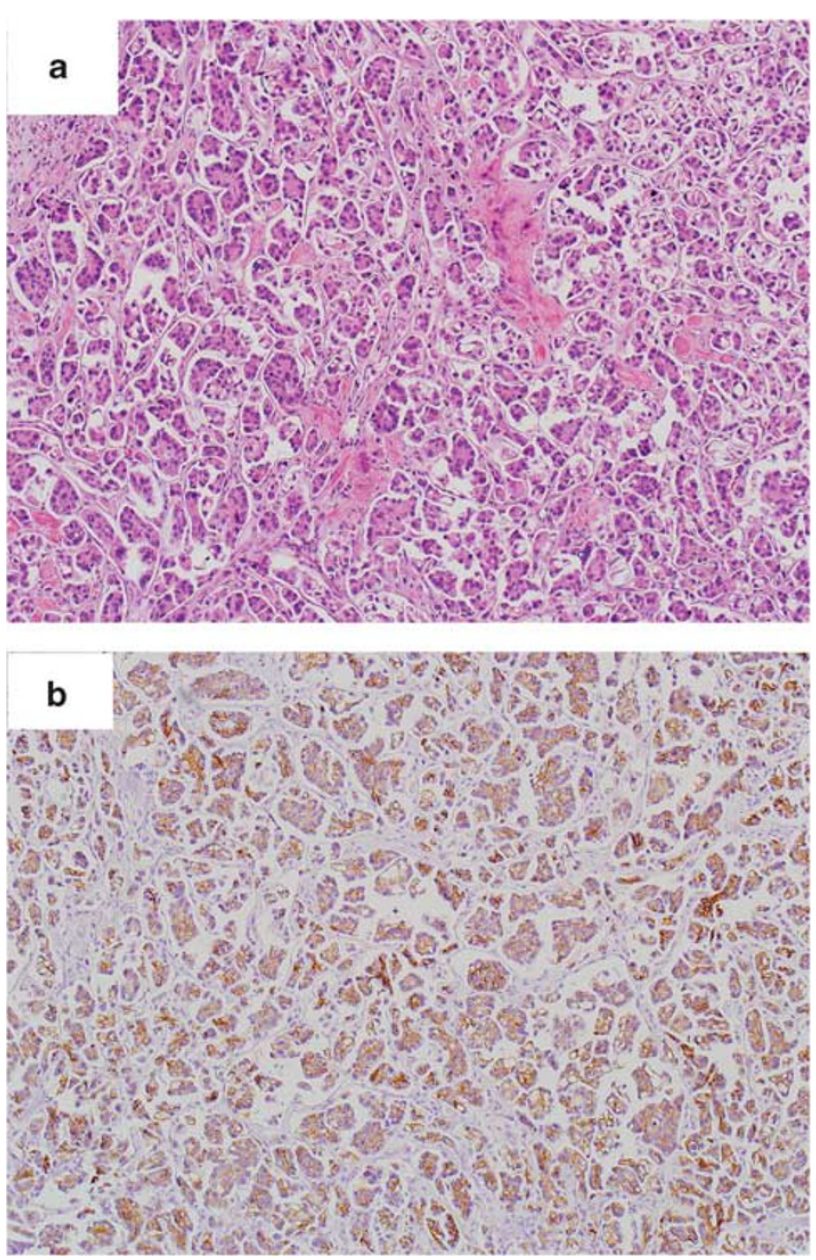

Figure 1 (a) Micropapillary urothelial carcinoma. (b) Positive E-cadherin expression in micropapillary urothelial carcinoma.

carcinoma with mixed plasmacytoid and signet ring cell differentiation were negative for E-cadherin. All nine additional cases of usual-type high-grade urothelial carcinoma were diffusely positive for E-cadherin (Figures $4 \mathrm{a}$ and b). $P$-value $\leqslant 0.0001$ for Fisher's exact test.

In the eight cases of micropapillary urothelial carcinoma, extravesical extension was present in three cases, muscularis propria invasion in four cases and lamina propria invasion in one case. In our four cases of plasmacytoid urothelial carcinoma, extravesical extension was present in two cases, muscularis propria invasion in one case and lamina propria invasion in one case. In our two cases of urothelial carcinoma with signet ring cell differentiation, extravesical extension was present in one case and muscularis propria invasion in the other. Of our two cases of urothelial carcinoma with mixed plasmacytoid and signet ring cell differentiation, muscularis propria invasion was present in one case and lamina propria invasion in the other. In our usual-type high-grade urothelial carcinoma, extravesical extension was present in six of nine cases. Of the nine cases, three were noninvasive.
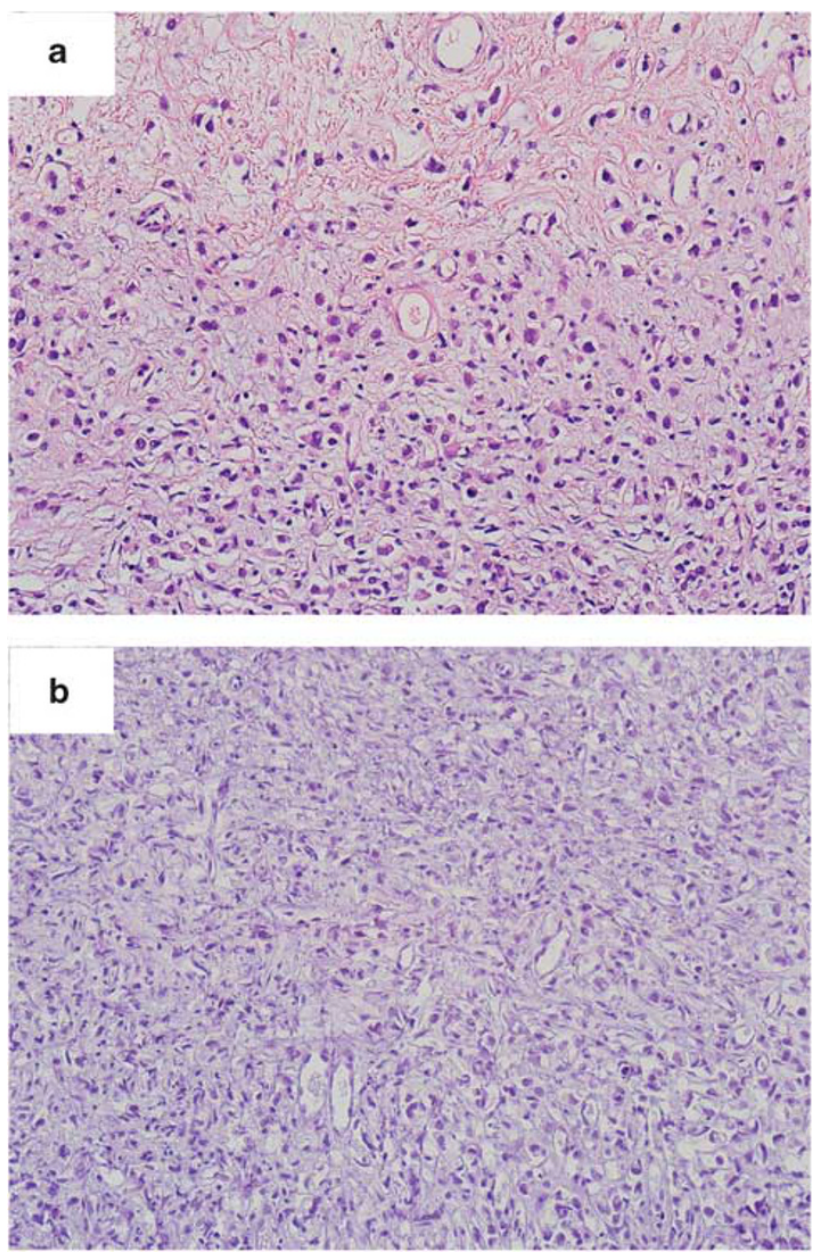

Figure 2 (a) Plasmacytoid urothelial carcinoma. (b) Negative E-cadherin expression in plasmacytoid urothelial carcinoma.

Angiolymphatic invasion was identified in all eight cases of micropapillary urothelial carcinoma, in two of four cases of plasmacytoid urothelial carcinoma, one of two cases of urothelial carcinoma with signet ring cell differentiation, one of two cases of urothelial carcinoma with mixed plasmacytoid and signet ring cell differentiation and in six of nine cases of usual-type high-grade urothelial carcinoma.

\section{Discussion}

Epithelial cells mediate important barrier functions. They form tight homotypic interactions that contribute to the formation of these permeability barriers. Cadherins are a family of transmembrane glycoproteins that are involved in homotypic calcium-dependent intercellular adhesions as well as cell signaling. E-cadherin is a $120 \mathrm{kDa}$ glycoprotein located on chromosome 16. This protein is expressed in all epithelial tissues and is associated with intracellular proteins called catenins that couple cadherins to actin microfilaments. ${ }^{26}$ The E-cadherin/catenin complex is important for cellular 

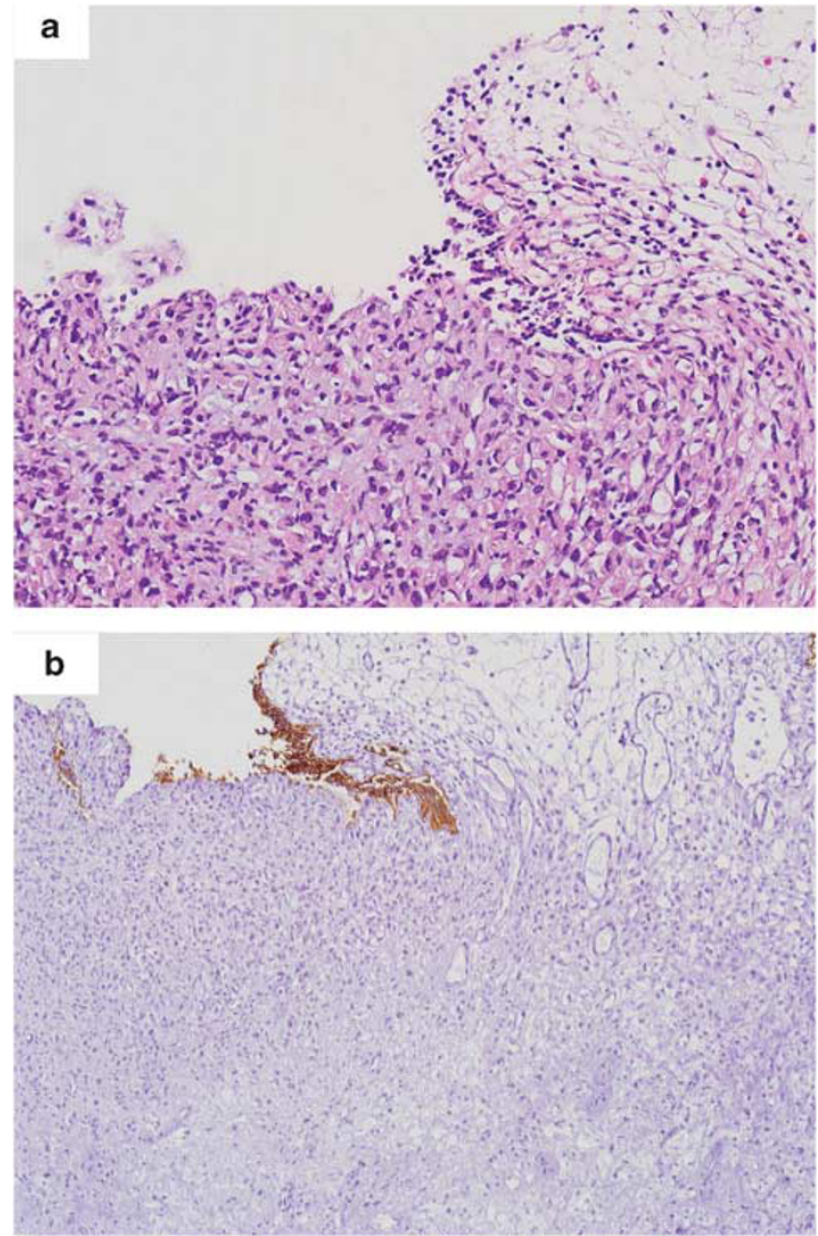

Figure 3 (a) Signet ring cell urothelial carcinoma, with overlying benign urothelium. (b) Negative E-cadherin expression in signet ring cell urothelial carcinoma (note positive expression in overlying benign urothelium).

polarity, maintenance of normal tissue morphology and cellular differentiation. ${ }^{27}$ Loss of E-cadherinmediated cell adhesion is involved in tumor progression and metastasis. There is also evidence that E-cadherin may have a role in invasion suppression. ${ }^{28}$

Recent studies have demonstrated that loss of E-cadherin immunoreactivity may correlate with a lack of differentiation and aggressive behavior of breast, head and neck, lung, gastric, esophageal, colorectal, prostatic and urothelial carcinomas. ${ }^{5-7,15,29-35}$ Published studies on urothelial carcinoma show that loss of membranous E-cadherin immunoreactivity is strongly correlated with high grade and advanced stage. ${ }^{8,12,15,36-38}$ Whether or not loss of E-cadherin is correlated with disease progression or has any prognostic significance has been debated by several investigators..$^{8,11,36,38-41}$ The nonvariant urothelial carcinoma in our study were diffusely positive for E-cadherin. Previous studies demonstrated a decreased or aberrant E-cadherin staining in tumors with deeper infiltration..$^{8,12,15,36-38,41}$ The staining intensity was heterogeneous in our cases, and there
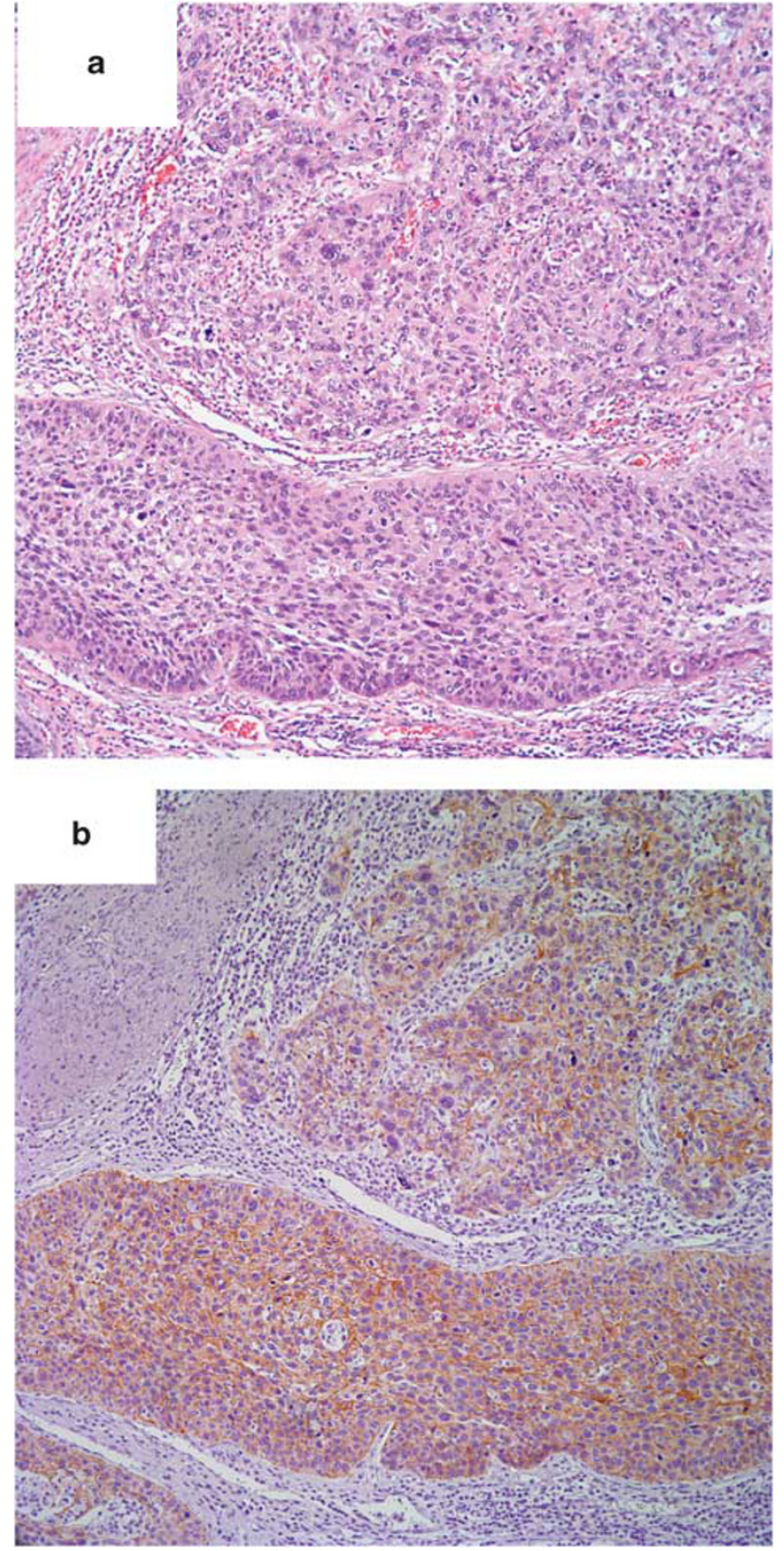

Figure 4 (a) Usual-type high-grade urothelial carcinoma. (b) Positive E-cadherin expression in usual-type high-grade urothelial carcinoma.

was no significant decrease or loss of staining in our high-grade carcinomas.

Recently, there has been an increased interest in the plasmacytoid variant of urothelial carcinoma. Three large series and numerous case reports have been published. ${ }^{21-23,42-60}$ This variant of urothelial carcinoma is considered to be a poorly differentiated neoplasm with aggressive behavior and poor prognosis. Microscopically, these tumors are diffusely infiltrative and the individual cells are often discohesive. Fritsche $e t a l^{43}$ put forth the hypothesis that E-cadherin loss may be associated with plasmacytoid differentiation in urothelial carcinoma. 
A review of the literature shows 13 total cases of plasmacytoid urothelial carcinoma that were stained with E-cadherin. All of these cases lacked E-cadherin expression. ${ }^{43,46,49,51,57}$ In our study, all four cases of plasmacytoid urothelial carcinoma, and two cases of urothelial carcinoma with mixed plasmacytoid and signet ring cell differentiation and urothelial carcinoma with signet ring cell differentiation lacked E-cadherin expression (Fisher's exact test, $P$-value $\leqslant 0.0001)$. Angiolymphatic invasion was identified in half of these cases and the depth of invasion ranged from lamina propria invasion to extravesical extension. These results are consistent with previous case reports of plasmacytoid urothelial carcinoma lacking E-cadherin staining. It is conceivable that loss of E-cadherin-mediated cell adhesion likely contributes to the lack of cohesion and infiltrative appearance of plasmacytoid urothelial carcinoma.

Plasmacytoid urothelial carcinoma may have intracytoplasmic vacuoles, giving them a resemblance to signet ring cells. ${ }^{21-23}$ We included two cases of urothelial carcinoma with signet ring cell differentiation. Signet ring cell carcinoma of the bladder has been associated with aggressive behavior and poor clinical outcome. ${ }^{61}$ In a series examining the immunohistochemical features of primary signet ring cell carcinomas of the bladder, Thomas et $a l^{62}$ found that E-cadherin was lost in three of nine cases. Both of our cases of urothelial carcinoma with signet ring cell differentiation lacked E-cadherin staining. Aberrant expression or loss of E-cadherin expression may be associated with the distinctive morphology of urothelial carcinoma with signet ring cell differentiation, and may also contribute to its aggressive behavior.

Micropapillary variant of urothelial carcinoma is associated with high grade and high stage, as well as a tendency for vascular invasion. Patients with this variant of urothelial carcinoma typically have a poor prognosis. The invasive component is composed of cells forming small tight nests and balls that are frequently seen in empty spaces devoid of cellular lining. ${ }^{24,25}$ Owing to its unique morphology and propensity for vascular invasion, we were interested in this variant's E-cadherin expression. Maranchie et al reported three cases of micropapillary urothelial carcinoma showing normal levels of E-cadherin expression. Of the three, one micropapillary carcinoma had an abnormal cytoplasmic distribution, despite normal membrane-bound staining of the adjacent micropapillary urothelial carcinoma. ${ }^{63}$ In another case report, E-cadherin staining was lost in the peripheral portions of cell clusters. ${ }^{64}$ In all eight of our cases of micropapillary urothelial carcinoma, E-cadherin expression was homogenously present in the membrane of the invasive component. Staining was not decreased or lost in the periphery of micropapillary cell clusters. All our cases had angiolymphatic invasion, and the depth of invasion ranged from lamina propria invasion to extravesical extension. Our results indicate that E-cadherin does not correlate with this lesion's high grade and stage or it's propensity for angiolymphatic invasion.

In addition to their distinct morphological features, loss of E-cadherin expression may be a marker of plasmacytoid and signet ring cell differentiation in urothelial carcinoma and may also have a role in the aggressive behavior of these variants of urothelial carcinoma.

\section{Disclosure/conflict of interest}

The authors declare no conflict of interest.

\section{References}

1 Takeichi M. The cadherins: cell-cell adhesion molecules controlling animal morphogenesis. Development 1988;102:639-655.

2 Shirayoshi Y, Okada TS, Takeichi M. The calciumdependent cell-cell adhesion system regulates inner cell mass formation and cell surface polarization in early mouse development. Cell 1983;35:631-638.

3 Otto T, Birchmeier W, Schmidt U, et al. Inverse relation of E-cadherin and autocrine motility factor receptor expression as a prognostic factor in patients with bladder carcinomas. Cancer Res 1994;54:3120-3123.

4 Rieger-Christ KM, Cain JW, Braasch JW, et al. Expression of classic cadherins type I in urothelial neoplastic progression. Hum Pathol 2001;32:18-23.

5 Oka H, Shiozaki H, Kobayashi K, et al. Expression of E-cadherin cell adhesion molecules in human breast cancer tissues and its relationship to metastasis. Cancer Res 1993;53:1696-1701.

6 Schipper JH, Frixen UH, Behrens J, et al. E-cadherin expression in squamous cell carcinomas of head and neck: inverse correlation with tumor dedifferentiation and lymph node metastasis. Cancer Res 1991;51: 6328-6337.

7 Umbas R, Schalken JA, Aalders TW, et al. Expression of the cellular adhesion molecule E-cadherin is reduced or absent in high-grade prostate cancer. Cancer Res 1992;52:5104-5109.

8 Bringuier PP, Umbas R, Schaafsma HE, et al. Decreased E-cadherin immunoreactivity correlates with poor survival in patients with bladder tumors. Cancer Res 1993;53:3241-3245.

9 Kawakita M, Moroi S, Kyotani K, et al. Study on E-cadherin expression in relation to invasion and metastasis in urothelial cancer patients. Hinyokika Kiyo 1994;40:1077-1080.

10 Miyazaki J, Fujisawa M, Arakawa S, et al. The expression of the E-cadherin in human urinary bladder carcinoma. Nippon Hinyokika Gakkai Zasshi 1995;86: 1208-1215.

11 Cai T, Piazzini M, Nesi G, et al. E-cadherin mRNA expression analysis in evaluating the natural history of urothelial bladder cell carcinoma: results from a longterm followup study. Oncol Rep 2007;17:925-930.

12 Erdemir F, Ozcan F, Kilicaslan I, et al. The relationship between the expression of Ecadherin and tumor recurrence and progression in high-grade stage T1 bladder urothelial carcinoma. Int Urol Nephrol 2007; 39:1031-1037. 
13 Sun W, Herrera GA. E-cadherin expression in urothelial carcinoma in situ, superficial papillary transitional cell carcinoma, and invasive transitional cell carcinoma. Hum Pathol 2002;33:996-1000.

14 Tsukino H, Kuroda Y, Nakao H, et al. E-cadherin gene polymorphism and risk of urothelial cancer. Cancer Lett 2003;195:53-58.

15 Sun W, Herrera GA. E-cadherin expression in invasive urothelial carcinoma. Ann Diagn Pathol 2004;8:17-22.

16 Okegawa T, Li Y, Pong RC, et al. Cell adhesion proteins as tumor suppressors. J Urol 2002;167:1836-1843.

17 McConkey DJ, Choi W, Marquis L, et al. Role of epithelial-to-mesenchymal transition (EMT) in drug sensitivity and metastasis in bladder cancer. Cancer Metastasis Rev 2009;28:335-344.

18 Fujisawa M, Miyazaki J, Takechi Y, et al. The significance of Ecadherin in transitional-cell carcinoma of the human urinary bladder. World J Urol 1996;14(Suppl 1):S12-S15.

19 Lopez-Beltran A, Cheng L. Histologic variants of urothelial carcinoma: differential diagnosis and clinical implications. Hum Pathol 2006;37:1371-1388.

20 Lopez-Beltran A, Requena MJ, Cheng L, et al. Pathological variants of invasive bladder cancer according to their suggested clinical significance. BJU Int 2008; 101:275-281.

21 Lopez-Beltran A, Requena MJ, Montironi R, et al. Plasmacytoid urothelial carcinoma of the bladder. Hum Pathol 2009;40:1023-1028.

22 Nigwekar P, Tamboli P, Amin MB, et al. Plasmacytoid urothelial carcinoma: detailed analysis of morphology with clinicopathologic correlation in 17 cases. Am J Surg Pathol 2009;33:417-424.

23 Ro JY, Shen SS, Lee HI, et al. Plasmacytoid transitional cell carcinoma of urinary bladder: a clinicopathologic study of 9 cases. Am J Surg Pathol 2008;32:752-757.

24 Amin MB, Ro JY, El-Sharkawy T, et al. Micropapillary variant of transitional cell carcinoma of the urinary bladder. Histologic pattern resembling ovarian papillary serous carcinoma. Am J Surg Pathol 1994;18: 1224-1232.

25 Johansson SL, Borghede G, Holmang S. Micropapillary bladder carcinoma: a clinicopathological study of 20 cases. J Urol 1999;161:1798-1802.

26 Mareel M, Boterberg T, Noe V, et al. E-cadherin/ catenin/cytoskeleton complex: a regulator of cancer invasion. J Cell Physiol 1997;173:271-274.

27 Grunwald GB. The structural and functional analysis of cadherin calcium-dependent cell adhesion molecules. Curr Opin Cell Biol 1993;5:797-805.

28 Vleminckx K, Vakaet Jr L, Mareel M, et al. Genetic manipulation of E-cadherin expression by epithelial tumor cells reveals an invasion suppressor role. Cell 1991;66:107-119.

29 Kadowaki T, Shiozaki H, Inoue $\mathrm{M}$, et al. E-cadherin and alpha-catenin expression in human esophageal cancer. Cancer Res 1994;54:291-296.

30 Kinsella AR, Lepts GC, Hill CL, et al. Reduced Ecadherin expression correlates with increased invasiveness in colorectal carcinoma cell lines. Clin Exp Metastasis 1994;12:335-342.

31 Oka H, Shiozaki H, Kobayashi K, et al. Immunohistochemical evaluation of Ecadherin adhesion molecule expression in human gastric cancer. Virchows Arch A Pathol Anat Histopathol 1992;421:149-156.

32 Doki Y, Shiozaki H, Tahara H, et al. Correlation between E-cadherin expression and invasiveness in vitro in a human esophageal cancer cell line. Cancer Res 1993;53:3421-3426.

33 Kinsella AR, Green B, Lepts GC, et al. The role of the cell-cell adhesion molecule Ecadherin in large bowel tumour cell invasion and metastasis. Br J Cancer 1993;67:904-909.

34 Matsuura K, Kawanishi J, Fujii S, et al. Altered expression of E-cadherin in gastric cancer tissues and carcinomatous fluid. Br J Cancer 1992;66:1122-1130.

35 Umbas R, Isaacs WB, Bringuier PP, et al. Decreased E-cadherin expression is associated with poor prognosis in patients with prostate cancer. Cancer Res 1994;54:3929-3933.

36 Byrne RR, Shariat SF, Brown R, et al. E-cadherin immunostaining of bladder transitional cell carcinoma, carcinoma in situ and lymph node metastases with long-term follow-up. J Urol 2001;165:1473-1479.

37 Syrigos KN, Krausz T, Waxman J, et al. E-cadherin expression in bladder cancer using formalin-fixed, paraffin-embedded tissues: correlation with histopathological grade, tumour stage and survival. Int J Cancer 1995;64:367-370.

38 Shimazui T, Schalken JA, Giroldi LA, et al. Prognostic value of cadherin-associated molecules (alpha-, beta-, and gamma-catenins and p120cas) in bladder tumors. Cancer Res 1996;56:4154-4158.

39 Hong $\mathrm{RL}, \mathrm{Pu} \mathrm{YS}$, Chu JS, et al. Correlation of expression of CD44 isoforms and Ecadherin with differentiation in human urothelial cell lines and transitional cell carcinoma. Cancer Lett 1995;89:81-87.

40 Lipponen PK, Eskelinen MJ. Reduced expression of E-cadherin is related to invasive disease and frequent recurrence in bladder cancer. J Cancer Res Clin Oncol 1995;121:303-308.

41 Mialhe A, Louis J, Montlevier S, et al. Expression of E-cadherin and alpha-, beta- and gamma-catenins in human bladder carcinomas: are they good prognostic factors? Invasion Metastasis 1997;17:124-137.

42 Chalasani V, Chin JL, Izawa JI. Histologic variants of urothelial bladder cancer and nonurothelial histology in bladder cancer. Can Urol Assoc J 2009;3:S193-S198.

43 Fritsche HM, Burger M, Denzinger S, et al. Plasmacytoid urothelial carcinoma of the bladder: histological and clinical features of 5 cases. J Urol 2008;180: 1923-1927.

44 Gaafar A, Garmendia M, de Miguel E, et al. Plasmacytoid urothelial carcinoma of the urinary bladder. A study of 7 cases. Actas Urol Esp 2008;32:806-810.

45 Kawashima A, Ujike T, Nin M, et al. Plasmacytoid urothelial carcinoma of the bladder: a case report. Nippon Hinyokika Gakkai Zasshi 2009;100:590-594.

46 Mai KT, Park PC, Yazdi HM, et al. Plasmacytoid urothelial carcinoma of the urinary bladder report of seven new cases. Eur Urol 2006;50:1111-1114.

47 McKenney JK, Amin MB. The role of immunohistochemistry in the diagnosis of urinary bladder neoplasms. Semin Diagn Pathol 2005;22:69-87.

48 Mitsogiannis IC, Ioannou MG, Sinani CD, et al. Plasmacytoid transitional cell carcinoma of the urinary bladder. Urology 2005;66:194.

49 Patriarca C, Di Pasquale M, Giunta P, et al. CD138positive plasmacytoid urothelial carcinoma of the bladder. Int J Surg Pathol 2008;16:215-217.

50 Sahin AA, Myhre M, Ro JY, et al. Plasmacytoid transitional cell carcinoma. Report of a case with initial presentation mimicking multiple myeloma. Acta Cytol 1991;35:277-280. 
51 Sato K, Ueda Y, Kawamura K, et al. Plasmacytoid urothelial carcinoma of the urinary bladder: a case report and immunohistochemical study. Pathol Res Pract 2009;205:189-194.

52 Shimada K, Nakamura M, Ishida E, et al. Urothelial carcinoma with plasmacytoid variants producing both human chorionic gonadotropin and carbohydrate antigen 19-9. Urology 2006;68:891 e897-810.

53 Soylu A, Aydin NE, Yilmaz U, et al. Urothelial carcinoma featuring lipid cell and plasmacytoid morphology with poor prognostic outcome. Urology 2005;65:797.

54 Zhang XM, Elhosseiny A, Melamed MR. Plasmacytoid urothelial carcinoma of the bladder. A case report and the first description of urinary cytology. Acta Cytol 2002;46:412-416.

55 Zukerberg LR, Harris NL, Young RH. Carcinomas of the urinary bladder simulating malignant lymphoma. A report of five cases. Am J Surg Pathol 1991;15:569-576.

56 Coyne JD, Sim E. Urothelial neoplasia with plasmacytoid morphology. Histopathology 2006;48:200-201.

57 Keck B, Stohr R, Goebell PJ, et al. Plasmacytoid carcinoma. Five case reports of a rare variant of urothelial carcinoma. Pathologe 2008;29:379-382.
58 Kohno T, Kitamura M, Akai H, et al. Plasmacytoid urothelial carcinoma of the bladder. Int J Urol 2006;13:485-486.

59 Lau SK. Cytomorphologic features of the plasmacytoid variant of urothelial carcinoma: a case report. Diagn Cytopathol 2009;37:359-364.

60 Shimada K, Nakamura M, Konishi N. A case of urothelial carcinoma with triple variants featuring nested, plasmacytoid, and lipoid cell morphology. Diagn Cytopathol 2009;37:272-276.

61 Grignon DJ, Ro JY, Ayala AG, et al. Primary signet-ring cell carcinoma of the urinary bladder. Am J Clin Pathol 1991;95:13-20.

62 Thomas AA, Stephenson AJ, Campbell SC, et al. Clinicopathologic features and utility of immunohistochemical markers in signet-ring cell adenocarcinoma of the bladder. Hum Pathol 2009;40:108-116.

63 Maranchie JK, Bouyounes BT, Zhang PL, et al. Clinical and pathological characteristics of micropapillary transitional cell carcinoma: a highly aggressive variant. J Urol 2000;163:748-751.

64 Lee JI. Micropapillary carcinoma of the urinary bladder: a case report. Acta Cytol 2009;53:344-348. 